\section{Evaluation of Pepper Root Rot Resistance in an Integrated Phytophthora Blight Management Program}

\author{
Charles S. Krasnow ${ }^{1,4}$, Andrew A. Wyenandt ${ }^{2,5}$, Wesley L. Kline ${ }^{2}$, \\ J. Boyd Carey ${ }^{3}$, and Mary K. Hausbeck ${ }^{1,6,7}$
}

AdDitional INDEX wORDs. Capsicum, oomycete, cultural, fungicides

Summary. Phytophthora crown and root rot, incited by Phytophthora capsici, is an important and limiting disease in bell pepper (Capsicum annuum) production in many vegetable-producing areas of the United States. Soilborne oospores initiate disease when conditions are favorable, and polycyclic production of sporangia and zoospores occurs on infected plant tissue during the production season. Raised-bed plant culture, resistant cultivars, and oomycete-specific fungicides are commonly used to manage $P$. capsici. The objective of this study was to evaluate four bell pepper cultivars and four experimental breeding entries (collectively termed entries) for resistance to $P$. capsici in Michigan (MI) and New Jersey (NJ) and to determine the effect of a fungicide program on plant health and yield. The pepper cultivars included Camelot X3R (susceptible), Aristotle (intermediately resistant), and Paladin and Archimedes (resistant) for comparison. Disease symptoms included plant wilting and sunken necrotic stem lesions. In NJ, blighting of stems and foliage was also observed. In MI, $>90 \%$ of the susceptible 'Camelot X3R' plants in the untreated plot wilted and died in both years of the study. All other entries had $<10 \%$ plant wilting and death in 2014. In 2015, 'Archimedes' and 'Paladin' had $<10 \%$ wilt and plant death; 'Aristotle', AP4835, 13SE12671, and AP4841 had 10\% to 30\% symptomatic plants. The fungicide program reduced disease to $<10 \%$ for all entries except 'Camelot X3R' in 2014 and 'Aristotle' and 'Camelot X3R' in 2015. In NJ, 'Paladin', 'Aristotle', and 'Camelot X3R' (2014) and 'Archimedes', 'Aristotle', and 'Camelot X3R' (2015) had $>30 \%$ plant wilting and death in the untreated plot. In the fungicide-treated plot, AP4841, AP4835, and AP4839 (2014), and AP4839 (2015) had $<10 \%$ of plants with disease symptoms; 'Camelot X3R' and 'Aristotle' had $>40 \%$ plant wilting and death in both years. In MI, marketable yield for 'Paladin' in fungicide-treated and untreated plots was significantly higher than the other entries in both years $(P<0.05)$. AP4839 was the highest yielding entry in NJ in the untreated plot, and AP4839 and 'Archimedes' were highest yielding in the fungicide-treated plot in 2014 and 2015, respectively. Fruit size for 13SE12671 was the largest among entries in both locations. There was no entry $\times$ fungicide program interaction in $\mathrm{MI}$.

$\mathrm{P}$ hytophthora crown and root rot is a destructive disease of pepper that causes significant annual losses throughout the United States (Hausbeck and Lamour, 2004; Ristaino and Johnston, 1999). Michigan and New Jersey are important

The authors thank Seminis Seeds Inc. for supplying seeds and financial support. Alex Cook for technical field assistance, and members of the Hausbeck Lab for valuable suggestions during this research.

${ }^{1}$ Department of Plant, Soil, and Microbial Sciences, Michigan State University, East Lansing, MI 48824

${ }^{2}$ Rutgers Agricultural Research and Education Center, Bridgeton, NJ 08302

${ }^{3}$ Monsanto Company, Creve Coeur, MO 63141

${ }^{4}$ Former graduate research assistant

${ }^{5}$ Extension specialist in vegetable pathology

${ }^{6}$ Professor

${ }^{7}$ Corresponding author. E-mail: hausbec1@msu.edu. doi: 10.21273/HORTTECH03697-17 producers of fresh market bell peppers in the Great Lakes and midAtlantic regions with a combined 5930 acres planted annually (U.S. Department of Agriculture, 2016). Yield loss can be severe when environmental conditions are suitable for disease (Hausbeck and Lamour, 2004; Lamour and Hausbeck, 2000; Ristaino and Johnston, 1999). Abundant sporangia are produced on infected plants, and motile zoospores liberated in free water contribute to the high disease potential and polycyclic spread of the pathogen (Bowers and Mitchell, 1991; Ristaino, 1991). Irrigation or surface runoff water infested with Phytophthora capsici propagules serves as a source of secondary inoculum (Gevens et al., 2007). Infected pepper plants develop irreversible wilt and plant death when temperatures are warm and soils saturated (Ristaino and Johnston, 1999). A necrotic lesion encircling the base of the crown is often apparent at advanced stages of infection. Disease may develop at any stage of growth, but young plants are considered most susceptible (Cafe-Filho and Duniway, 1996; Ristaino, 1991).

Raised-bed plant culture and trickle irrigation are used in fresh market pepper production to improve yields and reduce phytophthora infection (Bosland and Votava, 2012; Hausbeck and Lamour, 2004; Ristaino, 1991). Judicious application of fungicides via drip lines or as soil-directed sprays can provide additional control (Foster and Hausbeck, 2010; Kuhn et al., 2011; Meyer and Hausbeck, 2013). A drip-injected fungicide program that contained mandipropamid (Revus SC; Syngenta Crop Protection, Greensborough, NC) alternated with fluopicolide (Presidio SC; Valent Co., Walnut Creek, CA) provided $75 \%$ control of $P$. capsici root and crown rot of summer squash [Cucurbita pepo (Kuhn et al., 2011)]. When mandipropamid, fluopicolide, or dimethomorph (Forum; BASF Co., Florham Park, NJ) were applied weekly as soil drenches to summer

\begin{tabular}{lllc}
\hline $\begin{array}{l}\text { Units } \\
\text { To convert U.S. to SI, } \\
\text { multiply by }\end{array}$ & U.S. unit & SI unit & $\begin{array}{l}\text { To convert SI to U.S., } \\
\text { multiply by }\end{array}$ \\
\hline 0.4047 & $\mathrm{acre}(\mathrm{s})$ & $\mathrm{ha}$ & 2.4711 \\
29.5735 & $\mathrm{fl} \mathrm{oz}$ & $\mathrm{mL}$ & 0.0338 \\
0.3048 & $\mathrm{ft}$ & $\mathrm{m}$ & 3.2808 \\
0.0929 & $\mathrm{ft}^{2}$ & $\mathrm{~m}^{2}$ & 10.7639 \\
3.7854 & $\mathrm{gal}$ & $\mathrm{L}$ & 0.2642 \\
9.3540 & $\mathrm{gal} / \mathrm{acre}$ & $\mathrm{L} \cdot \mathrm{ha}^{-1}$ & 0.1069 \\
2.54 & inch(es) & $\mathrm{cm}$ & 0.3937 \\
1.1209 & $\mathrm{lb} / \mathrm{acre}$ & $\mathrm{kg} \cdot \mathrm{ha}^{-1}$ & 0.8922 \\
4.8824 & $\mathrm{lb} / \mathrm{ft}^{2}$ & $\mathrm{~kg} \cdot \mathrm{m}^{-2}$ & 0.2048 \\
28.3495 & $\mathrm{oz}$ & $\mathrm{g}$ & 0.0353 \\
6.8948 & $\mathrm{psi}$ & $\mathrm{kPa}$ & 0.1450
\end{tabular}


squash in MI, the incidence of phytophthora root rot was reduced to $\leq 10 \%$ compared with $100 \%$ for the control (Meyer and Hausbeck, 2013). Despite the effectiveness of soilapplied fungicides in phytophthora management, the labels of oomycetespecific fungicides may not support this application method (Bird et al., 2016; Sanogo and Ji, 2012; Wyenandt et al., 2016). In addition, the use of the fungicide mefenoxam (Ridomil; Syngenta Crop Protection) that was once highly effective in phytophthora management (Hausbeck and Lamour, 2004) is limited because of resistance in field populations of $P$. capsici (Café-Filho and Ristaino, 2008; Hausbeck and Lamour, 2004; Ploetz and Haynes, 2000). The paucity of fungicides that can be applied as soildrenches or via drip irrigation can negatively affect resistance management strategies including tank mixes and rotation of fungicide classes (Skylakakis, 1981; Staub and Sozzi, 1984).

Planting phytophthora-resistant and/or tolerant bell peppers is considered an optimal strategy to decrease fungicide use and improve yields (Hwang and Kim, 1995; Ristaino and Johnston, 1999; Wyatt et al., 2013). However, there are a limited number of pepper cultivars available that have high levels of resistance (Foster and Hausbeck, 2010). Breeding for resistance to $P$. capsici is a difficult and complex process. Root, stem, and foliar blight are considered to be under the action of separate genetic systems (Sy and Bosland, 2006; Walker and Bosland, 1999), and multiple genes must be introgressed to breed resistance to each disease syndrome. Seedling screens have been used to evaluate breeding lines and accessions of pepper and other vegetable crops for root rot resistance and can be performed relatively quickly in a greenhouse (Bolkan, 1985; Bosland and Lindsey, 1991; Foster and Hausbeck, 2010; Kim et al., 2012). However, pepper seedlings are more susceptible to $P$. capsici than mature plants (Café-Filho and Duniway, 1995; Hwang and Kim, 1990), and differences in the magnitude of agerelated resistance to the pathogen among pepper cultivars can affect disease severity (Hwang and Kim, 1995). P. capsici isolates also display significant differences in virulence, which can affect resistance screening (Granke et al., 2012). A study evaluating 12 Korean pepper cultivars for resistance to a worldwide collection of $P$. capsici isolates found significant differences in disease severity because of isolate (Kim and Hwang, 1992). In addition, $P$. capsici isolates recovered from vegetable hosts were shown to sporulate more on zucchini (C. pepo) fruit than the isolates from tropical hosts (Granke et al., 2012). Variations in P. capsici isolate virulence and pathogenicity based on geographical location and the host that the isolate was recovered from (Foster and Hausbeck, 2010; Islam et al., 2005; Polach and Webster, 1972) heighten the importance of selecting isolates that represent field populations in resistance screening (Granke et al., 2012; Kim and Hwang, 1992). The development and adoption of resistant cultivars is important as land suitable for vegetable production that is not infested with $P$. capsici is becoming increasingly limited (Hausbeck and Lamour, 2004; Quesada-Ocampo and Hausbeck, 2010), and soil fumigants that effectively disinfest soil are strictly regulated or have been phased out of production (Duniway, 2002).

The objective of this study was to evaluate the field performance of experimental entries and bell pepper cultivars with varying levels of resistance to phytophthora crown and root rot with and without fungicides.

\section{Materials and methods}

ENTRY SELECTION AND EXPERIMENTAL DESIGN. Seeds of selected pepper cultivars and experimental breeding entries were obtained from Seminis Seeds (St. Louis, MO). The commercial cultivars used in this study represented either high (Archimedes and Paladin) or intermediate (Aristotle) resistance to phytophthora root and crown rot (Foster and Hausbeck, 2010); Camelot X3R is considered susceptible. Experimental breeding entries (13SE12671, AP4835, AP4839, and AP4841) were known to have intermediate to high resistance based on preliminary field tests (A. Wyenandt, M. Hausbeck, and J. Carey, unpublished data). In both years, trials were duplicated across two locations; Southwest Michigan Research and Extension Center in Benton Harbor,
MI, and the Rutgers Agricultural Research and Education Center in Bridgeton, NJ. In each year, transplants were grown in 128-cell flats at the Michigan State University research greenhouses in East Lansing, $\mathrm{MI}$, and at a commercial transplant producer in Vineland, NJ. The MI field site consisted of loamy fine sand that was previously cropped to squash. The NJ soil type consisted of Outer Coastal Plain soil (Aura sandy loam). Both sites have a history of phytophthora root rot. In MI, fertilizer was broadcast preplant at the rate of 100 $\mathrm{lb} /$ acre nitrogen $(\mathrm{N}), 43.7 \mathrm{lb} /$ acre phosphorus (P), and $83.0 \mathrm{lb} /$ acre potassium (K) applied as $19 \mathrm{~N}-$ $8.3 \mathrm{P}-15.8 \mathrm{~K}$ and $50 \mathrm{lb} /$ acre $\mathrm{N}$ applied as $46 \mathrm{~N}-0 \mathrm{P}-0 \mathrm{~K}$. To control weeds, $0.37 \mathrm{lb} /$ acre clomazone (Command 3ME; FMC Co., Philadelphia, $\mathrm{PE}$ ), $0.05 \mathrm{lb} /$ acre halosulfuron (Sandea $75 \mathrm{~W}$; Gowan, Yuma, AZ), and $0.48 \mathrm{lb} /$ acre s-metolachlor (Dual Magnum 7.62 EC; Syngenta Crop Protection) were applied preplant between rows. Additional fertilizer was applied via drip irrigation every 1-2 weeks as $10 \mathrm{lb} /$ acre urea applied as $46 \mathrm{~N}-0 \mathrm{P}-0 \mathrm{~K}$ and $3 \mathrm{lb} /$ acre liquid $\mathrm{K}$ applied as $0 \mathrm{~N}-0 \mathrm{P}-23.2 \mathrm{~K}$. In $\mathrm{NJ}$, $50 \mathrm{lb} /$ acre $15.5 \mathrm{~N}-0 \mathrm{P}-0 \mathrm{~K}$ in the form of calcium nitrate fertilizer was broadcast preplant before bed formation. Clomazone $(0.37 \mathrm{lb} /$ acre $)$, halosulfuron $(0.05 \mathrm{lb} /$ acre $)$, and $\mathrm{s}$-metolachlor $(0.48 \mathrm{lb} / \mathrm{acre})$ were applied preplant under or between plastic mulch rows for weed control. Weekly fertigation was accomplished by applying $5 \mathrm{lb} /$ acre $20 \mathrm{~N}-8.7 \mathrm{P}-$ $16.6 \mathrm{~K}$ during the season.

Pepper seedlings that were $7-$ 8 weeks old were transplanted 12 inches apart into 6-inch raised plant beds covered with black polyethylene plastic with rows spaced $5.5 \mathrm{ft}$ apart on 6 and 16 June 2014 and 28 May and 11 June 2015 at MI and NJ, respectively. The bed top was about 3 $\mathrm{ft}$ across. Each treatment contained 18 plants with a 10 -ft buffer between treatments within the row. 'Camelot X3R' was planted in the buffer throughout the plot. In NJ in 2014 , only 14 plants per treatment were used because of a storm with hail that occurred during the hardening-off phase before transplanting. Extra plants from MI were used to supplement the trial in NJ due to the limited supply of plants. The trial was arranged as a completely 
randomized split plot design with fungicide program as the main plot and entry as subplot with four replications per treatment. In both years, the fungicide program consisted of fluopicolide injected into the drip lines at a rate of $56.0 \mathrm{~g} /$ acre at transplant and 30 and $60 \mathrm{~d}$ post planting (DPP), and mandipropamid applied at $56.0 \mathrm{~g} /$ acre as a directed foliar spray 14 DPP. In MI, fluopicolide was injected into the irrigation line of a single row with 25 psi carbon dioxide pressure from 3-gal canisters while irrigation was operating. Mandipropamid was applied at 50 psi using a backpack sprayer and a two-nozzle spray boom with flat fan nozzles (TeeJet XR8002; Spraying Systems Co., Wheaton, IL) directed at a $45^{\circ}$ angle toward the plant crown. In NJ, fluopicolide was administered using a system designed to deliver each treatment separately. Each main plot had a dedicated injector $(\mathrm{CH} 9000-210$ HN55 chemical injector; Chemilizer Products, Largo, FL) plumbed to its own irrigation line. The fungicide rate for each treatment was mixed into $500 \mathrm{~mL}$ of water in a 2 -L bottle for injection. Simultaneous drip applications were done with $\approx 30$-min water, followed by 30 -min application, followed by 30-min water to flush out drip lines. Mandipropamid was applied with a pressurized tractor-mounted sprayer delivered at $7.5 \mathrm{gal} /$ acre and 58 psi using three hollow-cone disc core drop nozzles (TeeJet D4-25; Spraying Systems Co.) with one placed over the top, and one on each side of the row directed at a $45^{\circ}$ angle toward the plant crown. Insects were controlled when necessary with drip applications of $229.5 \mathrm{~g} /$ acre imidacloprid (Admire Pro; Bayer, Pittsburgh, PA) at each location. The trials were conducted in 2014 and 2015.

InOculation. In MI, the plants were inoculated two and a half weeks after transplanting with $P$. capsiciinfested millet (Pennisetum glaucum) seed. Millet inoculum was prepared as previously described (QuesadaOcampo and Hausbeck, 2010) using $P$. capsici isolates OP97 [Al mating type, mefenoxam-sensitive, isolated from pickling cucumber (Cucumis satious) fruit] and 12889 ( $\mathrm{Al}$ mating type, mefenoxam-resistant, isolated from pepper fruit). The isolates were obtained from the culture collection of M.K. Hausbeck at Michigan State University and were inoculated into cucumber fruit and subsequently recovered from the diseased fruit to ensure isolate virulence prior to the study. Pepper plants were inoculated by placing $2 \mathrm{~g}$ of infested millet into a depression made in the soil $2-3 \mathrm{~cm}$ from the crown of a plant and covering with soil. Infested millet of each isolate was mixed $1: 1$ before inoculation. Plants were not inoculated in NJ and natural inoculum was relied on each year of the study.

Disease RATING AND HARVEST. At each location, the number of plants killed by $P$. capsici was counted each week and area under disease progress curve (AUDPC) values and the percentage of plants killed were calculated for each main plot. Fruit from all plants in a treatment row were harvested by hand five (2014) and four (2015) times in MI and seven times in NJ $(2014,2015)$. Pepper fruit that were unblemished, uniformly green, with three to four lobes were categorized using a scale developed to represent commercial standards for fresh market pepper sales in MI and NJ; Jumbo $=>230 \mathrm{~g}$, extra large $=190-229 \mathrm{~g}$, large $=$ $160-189 \mathrm{~g}$, medium $=130-159 \mathrm{~g}$, and small $=<130$ g. No. 2 fruit had irregular shape, minor blossom end rot, or superficial blemishes and were considered marketable to a processing or secondary market. Cull fruit were considered unmarketable because of $P$. capsici or fungal fruit rot, bacterial spot (Xanthomonas campestris), or insect damage.

Statistical anAlysis. Statistical software (SAS version 9.3; SAS Institute, Cary, NC) was used to analyze trial data. AUDPC values were calculated using disease incidence data and the method of Shaner and Finney (1977) and differences among AUDPC values were analyzed with Proc GLM $(P=0.05)$. Disease incidence data were analyzed with analysis of variance and Fisher's least significant difference test $(P=0.05)$. Differences in yield among treatments based on data taken as total fruit weight, total count, and mean marketable weight for individual fruit were analyzed with Proc Mixed for each location. Fungicide and entry were considered fixed effects and block a random effect. Yield data for each location was analyzed separately. There was no interaction of fruit weight with fungicide treatment within years at MI, and data were pooled before analysis. Normality of residual data was assessed with Proc Univariate and Proc Gplot.

\section{Results}

Wilting, sunken black lesions on the lower stem and crown, and girdling of the crown at the soil line were observed on diseased plants. In NJ, stem necrosis and foliar blighting was also observed. Uniformly high disease pressure occurred throughout each plot. In MI, there was no fungicide program $\times$ entry interaction $(P>$ $0.05)$, so AUDPC data were pooled. Final disease incidence was highest for 'Camelot X3R' in treated and untreated plots in 2014 and 2015; the AUDPC value was significantly higher than the other entries in 2014 (Table 1). All entries other than 'Camelot X3R' had $<10 \%$ incidence of wilt and plant death in fungicide-treated and untreated plots in 2014. 'Camelot X3R', AP4835, 'Aristotle', 13SE12671, and AP4841 had $>10 \%$ plant death in the untreated plot in 2015 and the AUDPC values for 'Camelot X3R' and 'Aristotle' were significantly higher than the other entries (Table 1). The fungicide program reduced disease to $<10 \%$ for all entries except 'Aristotle' and 'Camelot X3R'.

In NJ, the four experimental entries had $<10 \%$ wilt and plant death in 2014 in the untreated plot; however, disease incidence was between $8 \%$ and $34 \%$ in 2015 . Disease incidence was highest for 'Aristotle' and 'Camelot X3R' in the untreated plot in 2014 and 2015, respectively, with $>70 \%$ plant death (Table 2). AUDPC values for these cultivars were significantly higher than the other entries. The fungicide program reduced disease incidence significantly $[P<0.01$ (Table 2)]. In the fungicide-treated plots, disease incidence was $<10 \%$ for AP4835, AP4839, AP4841 (2014), and AP4839 (2015). 'Aristotle' and 'Camelot X3R' had $>40 \%$ plant death in the fungicide-treated plot each year. The AUDPC values for 'Paladin', 'Archimedes', AP4841, AP4839, and 13SE12671 were significantly lower than 'Camelot X3R' in 2015 in the fungicide-treated plot (Table 2).

'Paladin' yielded the largest number of marketable fruit in the untreated plot in both years in MI (Table 3). In 2014 , all entries in the fungicidetreated plot yielded similarly other than 'Camelot' and AP4841, which 
Table 1. Area under disease progress curve (AUDPC) values and incidence of plant death for pepper entries evaluated for resistance to phytophthora root rot in Michigan.

\begin{tabular}{|c|c|c|c|c|c|c|}
\hline \multirow[b]{3}{*}{ Resistance level, entry } & \multirow{2}{*}{\multicolumn{2}{|c|}{ AUDPC $^{z}$}} & \multicolumn{4}{|c|}{ Disease incidence $(\%)^{\mathrm{y}}$} \\
\hline & & & \multicolumn{2}{|c|}{ Untreated } & \multicolumn{2}{|c|}{ Treated } \\
\hline & 2014 & 2015 & 2014 & 2015 & 2014 & 2015 \\
\hline Camelot X3R & $5,353.9 \mathrm{a}^{\mathrm{x}}$ & $2,814.0 \mathrm{a}$ & $98.6 \mathrm{a}$ & $91.6 \mathrm{a}$ & $83.3 \mathrm{a}$ & $87.3 \mathrm{a}$ \\
\hline \multicolumn{7}{|l|}{ Intermediate to high } \\
\hline Aristotle & $401.4 \mathrm{~b}$ & $950.9 \mathrm{~b}$ & $8.3 \mathrm{~b}$ & $29.4 \mathrm{~b}$ & $4.2 \mathrm{bc}$ & $24.0 \mathrm{~b}$ \\
\hline $\mathrm{AP} 4841$ & $386.0 \mathrm{~b}$ & $276.5 \mathrm{~cd}$ & $4.2 \mathrm{~b}$ & $12.8 \mathrm{dc}$ & $4.3 \mathrm{bc}$ & $4.2 \mathrm{c}$ \\
\hline 13SE12671 & $203.1 \mathrm{~b}$ & $257.6 \mathrm{~cd}$ & $8.3 \mathrm{~b}$ & $11.1 \mathrm{dc}$ & $1.4 \mathrm{bc}$ & $2.8 \mathrm{c}$ \\
\hline \multicolumn{7}{|l|}{ Resistant } \\
\hline Archimedes & $340.7 \mathrm{~b}$ & $75.0 \mathrm{~d}$ & $2.8 \mathrm{~b}$ & $4.3 \mathrm{~d}$ & $1.4 \mathrm{bc}$ & $0.0 \mathrm{c}$ \\
\hline Paladin & $0.0 \mathrm{~b}$ & $23.3 \mathrm{~d}$ & $0.0 \mathrm{~b}$ & $1.4 \mathrm{~d}$ & $0.0 \mathrm{c}$ & $0.0 \mathrm{c}$ \\
\hline
\end{tabular}

${ }^{\mathrm{z}}$ AUDPC values were calculated from disease incidence data according to the method of Shaner and Finney (1977). AUDPC data were pooled from fungicide-treated and untreated plots as the fungicide $\times$ entry interaction was not significant $(P=0.05)$ in either year.

${ }^{\mathrm{y}}$ Disease incidence values based on percentage plants killed by phytophthora at the end of the season in both years. Values represent the mean of two trials with four replicate rows of 18 plants.

${ }^{\mathrm{x}}$ Column means with a letter in common are not significantly different according to Fisher's least significant difference test $(P=0.05)$.

Table 2. Area under disease progress curve (AUDPC) values and incidence of plant death for pepper entries evaluated for resistance to phytophthora root rot in New Jersey.

\begin{tabular}{|c|c|c|c|c|c|c|c|c|}
\hline \multirow[b]{3}{*}{$\underline{\text { Resistance level, entry }}$} & \multicolumn{4}{|c|}{ AUDPC $^{z}$} & \multicolumn{4}{|c|}{ Disease incidence $(\%)^{\mathrm{y}}$} \\
\hline & \multicolumn{2}{|c|}{ Untreated } & \multicolumn{2}{|c|}{ Treated } & \multicolumn{2}{|c|}{ Untreated } & \multicolumn{2}{|c|}{ Treated } \\
\hline & 2014 & 2015 & 2014 & 2015 & 2014 & 2015 & 2014 & 2015 \\
\hline Camelot X3R & $618.8 b^{x}$ & $5,011.8 \mathrm{a}$ & $2,387.5 \mathrm{a}$ & $3,038.2 \mathrm{a}$ & $16.1 \mathrm{bc}$ & $77.8 \mathrm{a}$ & $53.6 \mathrm{a}$ & $64.0 \mathrm{a}$ \\
\hline Intermediate to high & & & & & & & & \\
\hline Aristotle & $5,368.8 \mathrm{a}$ & $2,911.8 \mathrm{ab}$ & $2,981.3 \mathrm{a}$ & $1,973.6 \mathrm{ab}$ & $71.4 \mathrm{a}$ & $54.0 \mathrm{ab}$ & $51.8 \mathrm{a}$ & $41.8 \mathrm{ab}$ \\
\hline $\mathrm{AP} 4841$ & $81.3 \mathrm{~b}$ & $1,866.7 \mathrm{~b}$ & $0.0 \mathrm{c}$ & $724.3 \mathrm{~b}$ & $1.8 \mathrm{c}$ & $33.5 \mathrm{bc}$ & $0.0 \mathrm{c}$ & $23.8 \mathrm{~b}$ \\
\hline 13SE12671 & $356.3 \mathrm{~b}$ & $1,832.6 \mathrm{~b}$ & $2,187.5 \mathrm{ab}$ & $806.9 \mathrm{~b}$ & $5.4 \mathrm{c}$ & $32.0 \mathrm{bc}$ & $32.1 \mathrm{ab}$ & $19.5 \mathrm{~b}$ \\
\hline \multicolumn{9}{|l|}{ Resistant } \\
\hline Archimedes & $1,231.3 \mathrm{~b}$ & $1,759.7 \mathrm{~b}$ & $2,212.5 \mathrm{ab}$ & $680.6 \mathrm{~b}$ & $14.3 \mathrm{bc}$ & $34.8 \mathrm{abc}$ & $33.9 \mathrm{ab}$ & $14.0 \mathrm{~b}$ \\
\hline Paladin & $1,762.5 \mathrm{~b}$ & $1,419.4 \mathrm{~b}$ & $706.3 \mathrm{bc}$ & $836.1 \mathrm{~b}$ & $35.7 \mathrm{~b}$ & $23.5 \mathrm{bc}$ & $16.1 \mathrm{bc}$ & $12.5 \mathrm{~b}$ \\
\hline
\end{tabular}

${ }^{\mathrm{z}}$ AUDPC values were calculated from disease incidence data according to the method of Shaner and Finney (1977).

${ }^{y}$ Disease incidence values based on percentage plants killed by phytophthora at the end of the season both years. Values represent the mean of two trials with four replicate rows of $14(2014)$ and $18(2015)$ plants.

${ }^{\mathrm{x}}$ Column means with a letter in common are not significantly different according to Fisher's least significant difference test $(P=0.05)$.

produced fewer fruit ( $<146$ fruit/row). When fungicides were applied to 'Paladin', fruit count was significantly higher than the other entries in 2015 (Table 3). In NJ, AP4839 yielded the largest number of marketable fruit in the fungicide-treated and untreated plots in 2014 and in the untreated plot in 2015 (Table 3); 'Archimedes' yielded the largest number of fruit in the fungicide-treated plot in 2015 . Yield differences were not significant among entries by fruit count, with the exception of 'Camelot X3R' that yielded the lowest quantity of fruit in $2015(P>0.05)$. Total marketable yield by weight was highest for 'Paladin' in 2014 and 2015 in MI
(Fig. 1). In NJ, marketable yields were highest for AP4839 and 13SE12671 in 2014 and 2015, respectively (Fig. 2). Total marketable yield of entries were significantly different between years $(P<0.01)$; however, fungicides did not significantly improve marketable yields $(P=0.61)$.

In both years, 13SE12671 had the largest marketable fruit in MI (Table 4); fruit from 'Camelot X3R', AP4839, AP4841, and 'Aristotle' (2014), and 'Camelot X3R', AP4839, AP4841, and 'Paladin' (2015) were significantly smaller than 13SE12671. Similarly, 13SE12671 had the largest marketable fruit by weight in both years in NJ (Table 4). Fruit of
'Camelot X3R', AP4839, 'Paladin', and 'Archimedes' were significantly smaller than 13SE12671 in 2014 and the fruit of all entries were smaller in $2015[P<0.05$ (Table 4)]. In MI, 'Archimedes' and AP4839, and AP4841, and AP4839, had the greatest proportion of fruit graded as No. 2 in 2014 and 2015, respectively (data not shown). More than $50 \%$ of 'Camelot X3R' fruit were culls in both years; there were $<15 \%$ and $30 \%$ culls for the other entries in 2014 and 2015 , respectively. More than $40 \%$ of the fruit of 'Aristotle' and 'Paladin' were graded as cull both years in NJ (data not shown). 
Table 3. Mean total count of marketable fruit harvested from pepper entries evaluated for resistance to phytophthora root rot in Michigan (MI) and New Jersey (NJ).

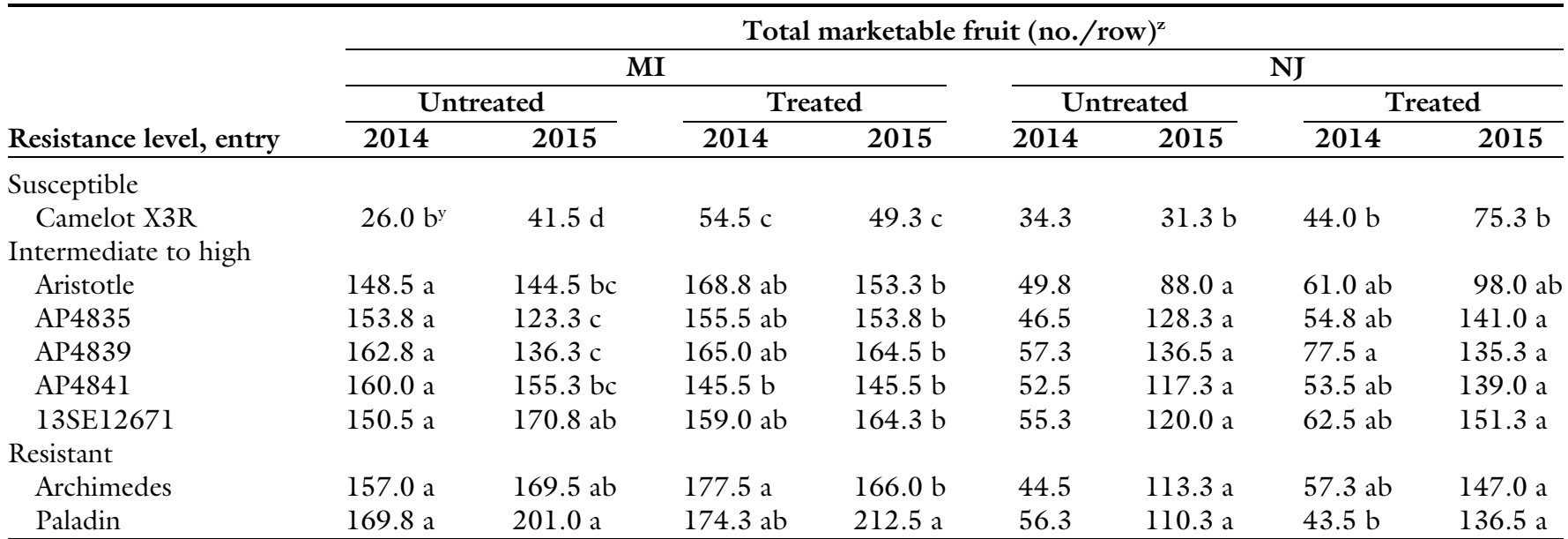

${ }^{\mathrm{z}}$ Mean count of marketable fruit (culls excluded) per $18 \times 3$ - $\mathrm{ft}(5.5 \times 0.9 \mathrm{~m})$ row harvested $5 \times$ and $4 \times(\mathrm{MI})$ and $7 \times$ and $7 \times(\mathrm{NJ})$ in 2014 and 2015 , respectively; 1 fruit $/$ row $=$ 0.0185 fruit $/ \mathrm{ft}^{2}=0.1993$ fruit $/ \mathrm{m}^{2}$.

${ }^{\mathrm{y}}$ Column means with a letter in common or without a letter are not significantly different according to Fisher's least significant difference test $(P=0.05)$.

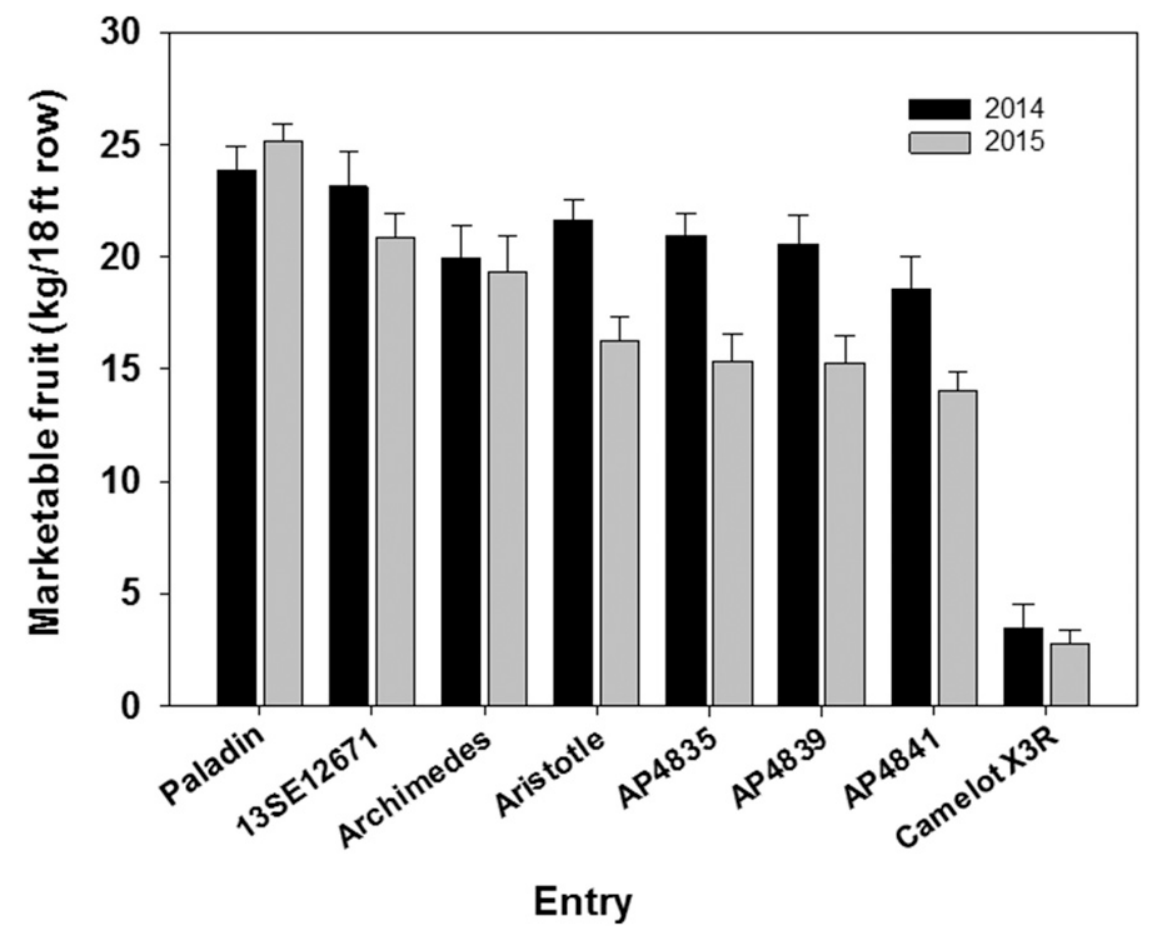

Fig. 1. Marketable fruit harvested from pepper entries evaluated for resistance to phytophthora root rot at the Southwest Michigan Research and Extension Center in Benton Harbor, MI, in 2014 and 2015. Error bars represent the SE; $1 \mathrm{~kg}$ per $18 \times 3$-ft $(5.5 \times 0.9 \mathrm{~m})$ row $=0.1993 \mathrm{~kg} \cdot \mathrm{m}^{-2}=0.0408 \mathrm{lb} / \mathrm{ft}^{2}$.

\section{Discussion}

Phytophthora blight annually threatens pepper production in the eastern United States and the Great Lakes growing regions (Hausbeck and Lamour, 2004; Ristaino and Johnston, 1999). Many vegetable crops are highly susceptible and the persistence of oospores contributes to growers' challenges in managing the disease (Hausbeck and Lamour, 2004; Hwang and Kim, 1995). Fungicides and cultural control strategies have been used in conjunction with cultivar resistance to reduce losses due to $P$. capsici (Ristaino and Johnston, 1999). However, the availability of phytophthora-resistant cultivars has been limited, and negative horticultural traits have been associated with some cultivars (Hwang and Kim, 1995). In the current study, entries with resistance to phytophthora crown and root rot displayed a range of disease responses in the $\mathrm{NJ}$ and MI research locations. In NJ, higher levels of disease were observed on 'Paladin', 'Aristotle', and 'Archimedes' than on the experimental entries. Limited disease developed on 'Paladin' and 'Archimedes' each year in MI, and resistance levels were comparable to the experimental entries. Bell pepper breeding lines and commercial cultivars with high levels of resistance to $P$. capsici root rot have been observed in recent field and greenhouse experiments (Dunn et al., 2014; Foster and Hausbeck, 2010; Wyatt et al., 2013). In New York field trials, 'Paladin', 'Intruder', and 'Archimedes' were resistant to phytophthora root rot (Dunn et al., 2014). Foster and Hausbeck (2010) inoculated pepper breeding lines and cultivars in the greenhouse at the 3-4-true leaf stage with $P$. capsici isolates from MI and found four breeding lines resistant to all isolates tested. 'Revolution', 'Paladin', and 'Declaration' had a high level of resistance in the former study; however, they were not resistant to all $P$. capsici isolates. Root rot and plant death of commercial pepper cultivars considered resistant to phytophthora have been observed in NJ field studies (Johnston et al., 2002). Annual production of 

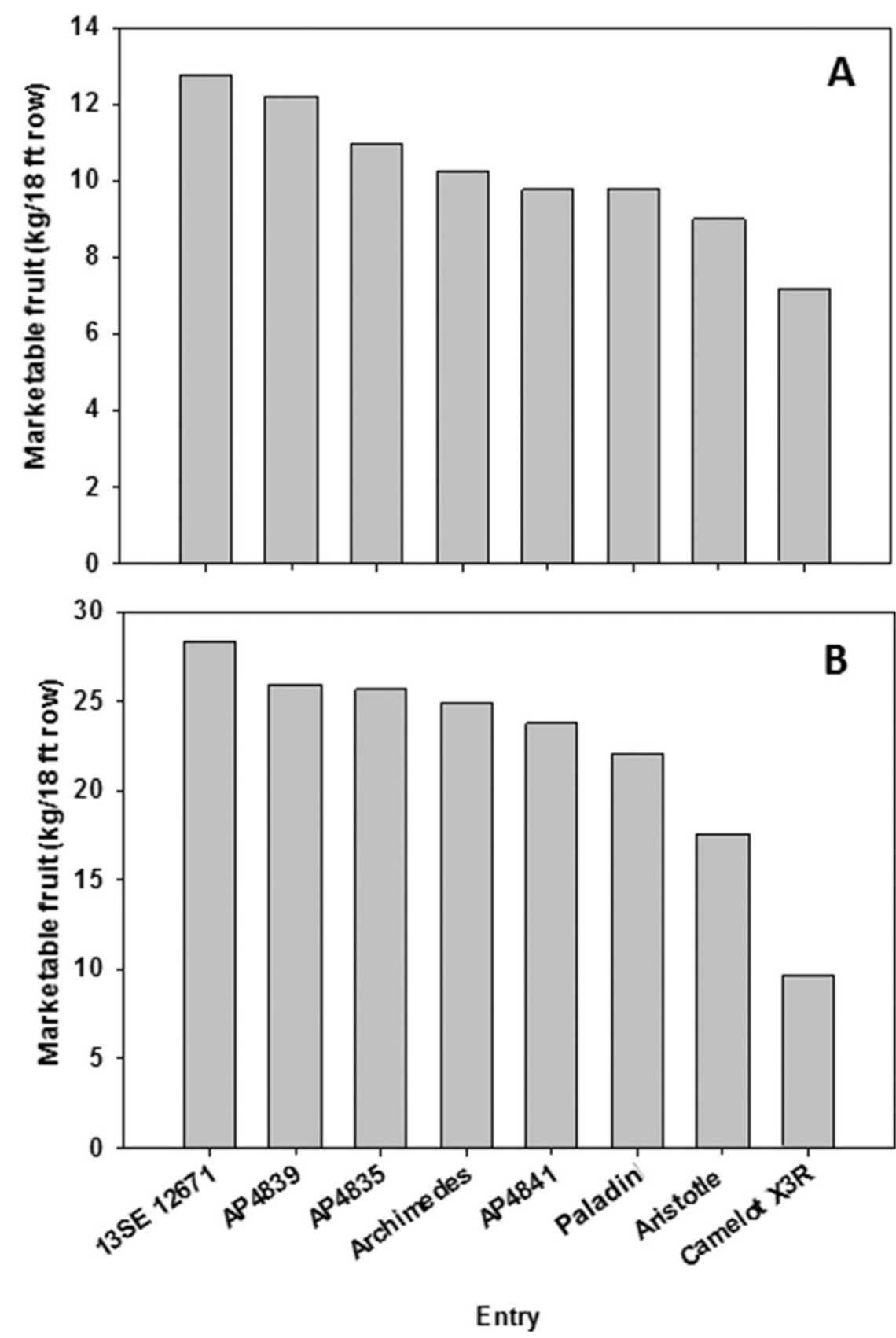

Fig. 2. Marketable fruit harvested from pepper entries evaluated for resistance to phytophthora root rot at the Rutgers Agricultural Research and Extension Center in Bridgeton, NJ, in (A) 2014 and (B) $2015 ; 1 \mathrm{~kg}$ per $18 \times 3-\mathrm{ft}(5.5 \times 0.9 \mathrm{~m})$ row $=$ $0.1993 \mathrm{~kg} \cdot \mathrm{m}^{-2}=0.0408 \mathrm{lb} / \mathrm{ft}^{2}$.

pepper in certain regions of $\mathrm{NJ}$ and a relatively long history of $P$. capsici (Ristaino and Johnston, 1999) may have favored isolates virulent to resistant cultivars. P. capsici can increase in virulence after sexual reproduction and genetic recombination of parent isolates (Satour and Butler, 1968), and $\mathrm{Al}$ and $\mathrm{A} 2$ mating types of $P$. capsici are present in major peppergrowing regions of the United States, often in the same field (Hausbeck and
NJ compared with the resistant cultivars suggests that those peppers had different genetic backgrounds. In addition, resistance of stems, leaves, and roots to $P$. capsici is considered to be under the action of separate genetic systems (Sy and Bosland, 2006; Walker and Bosland, 1999). Plant wilt and death of resistant cultivars in NJ could have been the result of splashing of infested soil onto stems and foliage (Elenkov, 1977; Schlub, 1983); large lesions developed on fully expanded detached leaves of mature plants of all entries in the current study after inoculation with a $P$. capsici-colonized V8-agar plug and incubation for $3 \mathrm{~d}$ in a moist chamber (C.S. Krasnow, unpublished data). Similarly, the fruit of root rot-resistant 'Paladin', 'Aristotle', 'Declaration', and 'Snapper' were susceptible to the pathogen (Foster and Hausbeck, 2010). Temperatures unfavorable for plant growth (Café-Filho and Duniway, 1995) and length of contact time with inoculum (Barksdale et al., 1984) are also known to affect disease development on resistant cultivars.

Large fruit size and uniform quality are desired for fresh market sales (Ristaino and Johnston 1999). In the current study, 'Paladin' was the highest yielding cultivar; however, fruit were smaller than other entries. Small fruit size has precluded adoption of some resistant cultivars (Ristaino and Johnston, 1999; Wyatt et al., 2013), especially where phytophthora blight is perceived as a minor problem (Hwang and Kim, 1995). In field trials in New York, breeding lines had high levels of root rot resistance; however, total yield and fruit size were lower than for the commercial cultivars tested (Wyatt et al., 2013). At both locations in the present study, 13SE12671 had a total marketable yield that was comparable to the commercially available cultivars; it also had the largest fruit size among entries, highlighting its potential horticultural value. Fruit silvering that has been correlated with resistance to phytophthora root rot (Wyenandt and Kline, 2006) was noted infrequently in this study (C.S. Krasnow, M.K. Hausbeck, and A.A. Wyenandt, unpublished data).

Yields increased and plant death was limited for most entries in the 
Table 4. Mean weight of individual marketable fruit harvested from pepper entries evaluated for resistance to phytophthora root rot in Michigan (MI) and New Jersey (NJ).

\begin{tabular}{|c|c|c|c|c|c|c|}
\hline \multirow[b]{4}{*}{ Resistance level, entry } & \multicolumn{6}{|c|}{ Marketable fruit wt $(\mathrm{g})^{\mathrm{z}}$} \\
\hline & \multirow{2}{*}{\multicolumn{2}{|c|}{ MI }} & \multicolumn{4}{|c|}{ NJ } \\
\hline & & & \multicolumn{2}{|c|}{ Untreated } & \multicolumn{2}{|c|}{ Treated } \\
\hline & $2014^{y}$ & 2015 & 2014 & 2015 & 2014 & 2015 \\
\hline \multicolumn{7}{|l|}{ Susceptible } \\
\hline Camelot X3R & $178.5 b c^{x}$ & $167.9 \mathrm{~b}$ & $181.6 \mathrm{c}$ & $184.3 \mathrm{~b}$ & $186.4 \mathrm{~b}$ & $185.8 \mathrm{bc}$ \\
\hline \multicolumn{7}{|l|}{ Intermediate to high } \\
\hline AP4839 & $177.4 \mathrm{bc}$ & $164.3 \mathrm{~b}$ & $187.0 \mathrm{bc}$ & $193.4 \mathrm{~b}$ & $190.2 \mathrm{ab}$ & $188.1 \mathrm{bc}$ \\
\hline $\mathrm{AP} 4841$ & $166.6 \mathrm{c}$ & $165.4 \mathrm{~b}$ & $196.2 \mathrm{abc}$ & $185.4 \mathrm{~b}$ & $192.5 \mathrm{ab}$ & $184.6 \mathrm{bc}$ \\
\hline 13SE12671 & $194.0 \mathrm{a}$ & $182.0 \mathrm{a}$ & $212.7 \mathrm{a}$ & $212.5 \mathrm{a}$ & $203.0 \mathrm{a}$ & $208.1 \mathrm{a}$ \\
\hline \multicolumn{7}{|l|}{ Resistant } \\
\hline Archimedes & $187.8 \mathrm{ab}$ & $172.8 \mathrm{ab}$ & $195.8 \mathrm{abc}$ & $191.1 \mathrm{~b}$ & $186.4 \mathrm{~b}$ & $193.5 \mathrm{~b}$ \\
\hline
\end{tabular}

current study as a result of the fungicide program. The importance of fungicides in a phytophthora management program was highlighted with a $>10 \%$ yield increase in AP4835, AP4839, 'Aristotle', and 'Camelot X3R' in 'MI, and all entries except 'Paladin' in NJ. Foliar fungicide sprays have traditionally been used to manage $P$. capsici diseases (Hausbeck and Lamour, 2004) but have been shown to be less effective than soil-directed sprays and applications via drip irrigation (Foster and Hausbeck, 2010; Meyer and Hausbeck, 2013). In a greenhouse trial, soil drenches reduced pepper root rot more than foliar sprays of the same fungicides (Foster and Hausbeck, 2010). Foliar sprays of fluopicolide did not protect tomato plants from $P$. capsici (Jiang et al., 2014). However, fluopicolide effectively reduced phytophthora blight of summer squash in field trials when applied as foliar sprays or through drip injection (Jackson et al., 2010). The reduction in root rot in the current study by combining resistant cultivars and fungicides was similar to that observed with a drip-applied fungicide program to protect the partially resistant 'Chieftain' winter squash (Cucurbita moschata) from phytophthora root rot (Hausbeck and Krasnow, 2014). Protection of 'Camelot X3R' was not greatly improved with fungicides, and a shortened application interval may be necessary with susceptible cultivars. Yeh and Kim (1991) suggested basing the number of fungicide applications on the resistance of the pepper cultivars planted. As 13SE12671 has high levels of root rot resistance and yielded similarly to commercially available resistant cultivars, performance in the Great Lakes and midAtlantic region could be expected. Additional research on $P$. capsicispecific fungicides that optimize the yield of resistant cultivars would be beneficial.

\section{Literature cited}

Barksdale, T., G. Papavizas, and S. Johnston. 1984. Resistance to foliar blight and crown rot of pepper caused by Phytophthora capsici. Plant Dis. 68:506-508.

Bird, G., M. Hausbeck, L. Jess, W. Kirk, Z. Szendrei, and F. Warner. 2016. Insect, disease and nematode control for commercial vegetables. Michigan State Univ. Ext. Bul. E-312.

Bolkan, H.A. 1985. A technique to evaluate tomatoes for resistance to phytophthora root-rot in the greenhouse. Plant Dis. 69:708-709.

Bosland, P.W. and D.L. Lindsey. 1991. A seedling screen for phytophthora root rot of pepper, Capsicum annuum. Plant Dis. 75:1048-1050.

Bosland, P.W. and E.J. Votava. 2012. Peppers: Vegetable and spice capsicums. 2nd ed. CABI, Cambridge, MA.

Bowers, J.H. and D.J. Mitchell. 1991. Relationship between inoculum level of Phytophthora capsici and mortality of pepper. Phytopathology 81:178-184.
Café-Filho, A. and J. Duniway. 1995. Effects of furrow irrigation schedules and host genotype on phytophthora root rot of pepper. Plant Dis. 79:4448 .

Cafe-Filho, A.C. and J.M. Duniway. 1996. Effect of location of drip irrigation emitters and position of Phytophthora capsici infections in roots on phytophthora root rot of pepper. Phytopathology 86:1364-1369.

Café-Filho, A.C. and J.B. Ristaino. 2008. Fitness of isolates of Phytophthora capsici resistant to mefenoxam from squash and pepper fields in North Carolina. Plant Dis. 92:1439-1443.

Duniway, J. 2002. Status of chemical alternatives to methyl bromide for pre-plant fumigation of soil. Phytopathology 92: 1337-1343.

Dunn, A.R., H.W. Lange, and C.D. Smart. 2014. Evaluation of commercial bell pepper cultivars for resistance to phytophthora blight (Phytophthora capsici). Plant Health Prog. 15:19-24.

Elenkov, E. 1977. Phytophthora capsici on peppers in greenhouses. Acta Hort. 58:401-404.

Foster, J. and M. Hausbeck. 2010. Resistance of pepper to phytophthora crown, root, and fruit rot is affected by isolate virulence. Plant Dis. 94:24-30.

Foster, J.M. and M.K. Hausbeck. 2010. Managing phytophthora crown and root rot in bell pepper using fungicides and host resistance. Plant Dis. 94:697-702.

Gevens, A.J., R.S. Donahoo, K.H. Lamour, and M.K. Hausbeck. 2007. Characterization of Phytophthora capsici 
from Michigan surface irrigation water. Phytopathology 97:421-428.

Granke, L., L. Quesada, and M. Hausbeck. 2012. Differences in virulence of Phytophthora capsici isolates from a worldwide collection on host fruits. Eur. J. Plant Pathol. 132:281-296.

Hausbeck, M.K. and C.S. Krasnow. 2014. Watch for phytophthora on vine crops. 1 Sept. 2016. <http://msue.anr.msu.edu/ news/watch_for_phytophthora_on_ vine_crops $>$.

Hausbeck, M.K. and K.H. Lamour. 2004. Phytophthora capsici on vegetable crops: Research progress and management challenges. Plant Dis. 88:1292-1303.

Hwang, B.K. and C.H. Kim. 1995. Phytophthora blight of pepper and its control in Korea. Plant Dis. 79:221-227.

Hwang, B.K. and Y.J. Kim. 1990. Capsidiol production in pepper plants associated with age-related resistance to Phytophthora capsici. Korean J. Plant Pathol. 6:193-200.

Islam, S.Z., M. Babadoost, K.N. Lambert, A. Ndeme, and H.M. Fouly. 2005. Characterization of Phytophthora capsici isolates from processing pumpkin in Illinois. Plant Dis. 89:191-197.

Jackson, K.L., J.F. Yin, A.S. Csinos, and P.S. Ji. 2010. Fungicidal activity of fluopicolide for suppression of Phytophthora capsici on squash. Crop Prot. 29:14211427.

Jiang, L., H. Wang, H. Xu, K. Qiao, X. Xia, and K. Wang. 2014. Transportation behaviour of fluopicolide and its control effect against Phytophthora capsici in greenhouse tomatoes after soil application. Pest Mgt. Sci. 71:1008-1014.

Johnston, S.A., W.L. Kline, M.L. Fogg, and M.D. Zimmerman. 2002. Varietal resistance evaluation for control of phytophthora blight of pepper. Phytopathology 92:S40 (abstr.).

Kim, F.S. and B.K. Hwang. 1992. Virulence to Korean pepper cultivars of isolates of Phytophthora capsici from different geographic areas. Plant Dis. 76:486-489.

Kim, M.J., C.K. Shim, Y.K. Kim, H.J. Jee, S.J. Hong, J.H. Park, M.H. Lee, and E.J. Han. 2012. Screening of resistance melon germplasm to phytophthora rot caused by Phytophthora capsici. Korean J. Crop Sci. 57:389-396.

Kuhn, P., M. Babadoost, D. Thomas, P. Ji, H. McLean, A. Hert, D. Tory, and A. Tally. 2011. Evaluation of drip applications of Revus in fungicide programs for management of phytophthora blight (Phytophthora capsici) on bell pepper and squash. Phytopathology 101:S94 (abstr.).

Lamour, K.H. and M.K. Hausbeck. 2000. Mefenoxam insensitivity and the sexual stage of Phytophthora capsici in Michigan cucurbit fields. Phytopathology 90:396400 .

Meyer, M.D. and M.K. Hausbeck. 2013. Using soil-applied fungicides to manage phytophthora crown and root rot on summer squash. Plant Dis. 97:107-112.

Palloix, A., A. Daubeze, and E. Pochard. 1988. Phytophthora root rot of pepper influence of host genotype and pathogen strain on the inoculum density-disease severity relationships. J. Phytopathol. 123 : 25-33.

Ploetz, R., G. Heine, J. Haynes, and M. Watson. 2002. An investigation of biological attributes that may contribute to the importance of Phytophthora capsici as a vegetable pathogen in Florida. Ann. Appl. Biol. 140:61-67.

Ploetz, R.C. and J.L. Haynes. 2000. How does Phytophthora capsici survive in squash fields in southeastern Florida during the off-season. Proc. Florida State Hort. Soc. 113:211-215.

Polach, F. and R. Webster. 1972. Identification of strains and inheritance of pathogenicity in Phytophthora capsici. Phytopathology 62:20-26.

Quesada-Ocampo, L.M. and M.K. Hausbeck. 2010. Resistance in tomato and wild relatives to crown and root rot caused by Phytophthora capsici. Phytopathology 100:619-627.

Ristaino, J.B. 1990. Intraspecific variation among isolates of Phytophthora capsici from pepper and cucurbit fields in North Carolina. Phytopathology 80: 1253-1259.

Ristaino, J.B. 1991. Influence of rainfall, drip irrigation, and inoculum density on the development of phytophthora root and crown rot epidemics and yield in bell pepper. Phytopathology 81:922-929.

Ristaino, J.B. and S.A. Johnston. 1999. Ecologically based approaches to management of phytophthora blight on bell pepper. Plant Dis. 83:1080-1089.

Sanogo, S. and P. Ji. 2012. Integrated management of Phytophthora capsici on solanaceous and cucurbitaceous crops: Current status, gaps in knowledge and research needs. Can. J. Plant Pathol. 34:479-492

Satour, M.M. and E.E. Butler. 1968. Comparative morphological and physiological studies of progenies from intraspecific matings of Phytophthora capsici. Phytopathology 58:183-192.

Schlub, R. 1983. Epidemiology of Phytophthora capsici on bell pepper. J. Agr. Sci. 100:7-12.

Shaner, G. and R. Finney. 1977. The effect of nitrogen fertilization on the expression of slow-mildewing resistance in Knox wheat. Phytopathology 67:10511056.

Skylakakis, G. 1981. Effects of alternating and mixing pesticides on the buildup of fungal resistance. Phytopathology 71: 1119-1121.

Staub, T. and D. Sozzi. 1984. Fungicide resistance - A continuing challenge. Plant Dis. 68:1026-1031.

Sy, O. and P.W. Bosland. 2006. Inheritance of phytophthora stem blight, root rot, and foliar blight resistance in capsicum. HortScience 41:1047.

U.S. Department of Agriculture. 2016. Vegetables summary 2015. 10 Sept. 2016. <http://usda.mannlib.cornell.edu/usda/ current/VegeSumm/VegeSumm-02-042016.pdf>.

Walker, S.J. and P.W. Bosland. 1999. Inheritance of phytophthora root rot and foliar blight resistance in pepper. J. Amer. Soc. Hort. Sci. 124:14-18.

Wyatt, L.E., A.R. Dunn, M. Falise, S. Reiners, M. Jahn, C.D. Smart, and M. Mazourek. 2013. Red harvest yield and fruit characteristics of Phytophthora capsici-resistant bell pepper inbred lines in New York. HortTechnology 23:356363.

Wyenandt, A., G. Hamilton, T. Kuhar, E. Sanchez, and M. VanGessell. 2016. MidAtlantic commercial vegetable production recommendations. Rutgers Univ. New Jersey Agr. Expt. Sta. Coop. Ext. Bul. E001.

Wyenandt, C.A. and W.L. Kline. 2006. Evaluation of skin separation (silvering) in fruit of bell pepper cultivars. HortScience $41: 494$

Yeh, W. and C. Kim. 1991. Integrated management of phytophthora blight of red-pepper by host resistance and fungicide application. Korean J. Plant Pathol. 7:226-229. 